\title{
Conclusion: An Awareness of Alternatives
}

\begin{abstract}
My findings show that contemporary and historiographical discourses which predominantly frame migration as a problem to be tackled, neglect the historical evidence for sociopolitical innovation that can, at times, result from international, transnational, internal, and even indirect experiences of migration. For instance, this book gives various examples that show how the existence of privilege and discrimination can generate social change. To illuminate such links between migration and gender innovation does not mean glorifying migration or propagating a naïve notion of diversity. Migration is per se neither good nor bad, but the conditions under which it takes place are good or bad, and these conditions are made, not given. The political, economic, and social conditions under which migration takes place depend on how past and present migration is perceived. This is precisely why, today, we have to make visible these often hidden histories. Looking at history through the lens of migration not only adds new insights to an established body of work, but changes the perspective under which our past and thus also our present is told-and our future imagined.
\end{abstract}

Keywords Anti-Muslim racism - The fear of 'Italianisation' • Limitations of this study $\cdot$ Past $\cdot$ Present $\cdot$ Future

F. Falk, Gender Innovation and Migration in Switzerland, Palgrave Studies in Migration History, https://doi.org/10.1007/978-3-030-01626-5_7 


\section{Equal Rights Presented as Being Endangered by Migration}

Equal rights are often presented as being endangered by migration. For example, in the case of Switzerland, a constitutional ban on minarets has been legitimised by a prominent feminist with reference to women's rights. ${ }^{1}$ In academia, two prominent political scientists have claimed that the 'true clash of civilisations' would concern 'gender equality and sexual liberalisation'. ${ }^{2}$ Today, when gender equality is perceived as being endangered by migration, suspicion is primarily focused on Muslim 'migrants'. However, in the boom years after the Second World War, this was not a prominent issue in Switzerland. In the public debates of the 1960s, the religious affiliation of workers from Turkey and certain territories of former Yugoslavia in fact played a minor role. ${ }^{3}$

Interestingly, in those years, Italians ${ }^{4}$ were often presented in a similar way to Muslims today. Of course, this does not imply that there

\footnotetext{
${ }^{1}$ However, Julia Onken's argumentation was criticised by different women's groups, see for example http://www.inforel.ch/fileadmin/user_upload/dateien/OffenerBriefJuliaOnken. pdf (23 June 2016) as well as Elisabeth Joris and Katrin Rieder, Not in our name, in Gross, Krebs, Schaffner, and Stohler, Von der Provokation zum Irrtum. Menschenrechte und Demokratie nach dem Minarett-Bauverbot, St-Ursanne: Editions le Doubs 2010, 25-36. In this context, see also Stefanie C. Boulila, Insignificant Signification: A Feminist Critique of the Anti-Muslim Feminist, in Hafez, Jabrbuch für Islamophobieforschung, Wien: New Academic Press 2013, 88-103. Carolin Fischer and Janine Dahinden, Changing Gender Representations in Politics of Belonging: A Critical Analysis of Developments in Switzerland (2016), http://nccr-onthemove.ch/publications/changing-gender-representations-in-politics-of-belonging-a-critical-analysis-of-developments-in-switzerland (1 December 2016).

${ }^{2}$ Ronald Inglehart and Pippa Norris, The True Clash of Civilizations, Foreign Policy (2003), 62-70, 64-65. For a critique of this position, see Éric Fassin, National Identities and Transnational Intimacies: Sexual Democracy and the Politics of Immigration in Europe, Public Culture. An Interdisciplinary Journal of Transnational Cultural Studies 22,
} 3 (2010), 507-529.

${ }^{3}$ Giuseppe De Simone, Von Türken und Kurden zu Muslimen? Eine Untersuchung der Berichterstattung in den Schweizer Printmedien über die Einwanderer aus der Türkei, 1960-2006, in Ideli, Suter Reich, and Kieser, Nene Menschenlandschaften. Migration Türkei - Schweiz 1961-2011, Zürich: Chronos 2011, 141-158; Samuel-Martin Behloul, Muslime als die neuen 'Anderen'. 9/11 und die Folgen, in Tangram 6 (2013), 70-73; Thomas Bürgisser, Wahrnehmungwandel der jugoslawischen Migrationsbevölkerung, Tangram 6 (2013), 42-46; Patrik Ettinger, Muslime in den Medien zunehmend problematisiert, Tangram 12 (2017), 69-74.

${ }^{4}$ This applies to other groups as well. In general, people from the 'south' and later on from ex-Yugoslavia were perceived in this way. 
are no differences between the past depiction of Italian migration and the current representation of Muslim migration to Switzerland. For instance, even though Italians were seen as causing a religious imbalance in Switzerland, the image of the Italians was not reduced to religion and in fact oscillated between Italians as associated with either conservatism or communism. In addition, Italians were never linked as closely to the topic of terrorism as Muslims are today, even though 'Italian Communists working in Switzerland [...] were seen as a potential security threat'. ${ }^{5}$ Furthermore, since Italians were perceived as being more fertile than the Swiss, it was feared that an 'Italianisation' of the Swiss population could not be prevented. ${ }^{6}$ Likewise-and somewhat ironically, in a country where many prided themselves on owning a Swiss army knife and where men kept their military rifles at home-Italians men were perceived as dangerous because they were allegedly wont to carry switchblades. ${ }^{7}$ Other customs that met with disapproval were the black mourning clothes worn by some Italian widows and the fact that, in church, certain Italian women wore a veil. ${ }^{8}$ Moreover, 'migrants' liked to use railway stations as meeting points, ${ }^{9}$ and such gatherings were viewed critically, in part because Italians were considered more likely to sexually harass Swiss women. ${ }^{10}$ For example, in 1983, a snack bar in the

\footnotetext{
${ }^{5}$ Mark James Miller, Foreign Workers in Western Europe. An Emerging Political Force, New York: Praeger 1981, 5.

${ }^{6}$ E.H., Briefe an die NZZ. Italianisierung der Schweiz?, in Neue Zürcher Zeitung, 11 September 1964 (Mittagsausgabe) (1964), 59. See also Damir Skenderovic, Die Macht rechtspopulistischer Aussenseiter in den 1960er bis 1980er Jahren, in Skenderovic and D'Amato, Mit dem Fremden politisieren. Rechtspopulistische Parteien und Migrationspolitik in der Schweiz seit den 1960er Jahren, Zürich: Chronos 2008, 31-67, 42.

${ }^{7}$ Thomas Buomberger, Kampf gegen unerwünschte Fremde. Von James Schwarzenbach bis Christoph Blocher, Zürich: Orell Füssli 2004, 81.

${ }^{8}$ Marc Virot, Vom Anderssein zur Assimilation. Merkmale zur Beurteilung der Assimilationsreife der Ausländer in der Schweiz, Bern: Haupt 1968, 59.

${ }^{9}$ This was also the case in Germany: Sabine Hess, Politiken der (Un-)Sichtbarmachung. Eine Kritik der Wissens- und Bilderproduktion zu Migration, in Yildiz and Hill, Nach der Migration. Postmigrantische Perspektiven jenseits der Parallelgesellschaft, Bielefeld: Transcript 2015, 49-64, 50 .

${ }^{10}$ Angelo Maiolino, Die 'Tschinggen' und die Schwarzenbach-Initiative. Von der Politik der Marginalisierten zur Mediterranisierung der Schweiz (2012), http://www.terra-cognita.ch/fileadmin/user_upload/terracognita/documents/terra_cognita_21.pdf (15 June 2016). Angelo Maiolino, Als die Italiener noch Tschinggen waren. Der Widerstand gegen die Schwarzenbach-Initiative, Zürich: Rotpunktverlag 2011.
} 
town of Will refused to seat Italians towards the front of the premises, claiming that unaccompanied women would no longer dare to enter. ${ }^{11}$ In addition, regardless of Swiss society's own shortcomings regarding gender equality, Italian families were often characterised as patriarchal. Remarkably, the topic of the 'isolated foreign wife' can also be found in these years. In a report published in 1976 by the 'Federal Advisory Commission for the Foreigner Problem', it was acknowledged, for instance, that the employment rate among married foreign women was relatively high. Nonetheless, the report stated that wives coming from southern regions lived more narrowly within the family circle than Swiss women, having little opportunity for contact with the outside world. ${ }^{12}$ The stereotypical images of the 'oppressed and isolated Muslima' and the 'patriarchal Muslim' thus possess some traits that, from a historical perspective, are quite familiar. Such a characterisation recalls once again the strategies of legitimisation associated with colonialism, condensed in Gayatri Spivak's words that 'White men are saving brown women from brown men'. ${ }^{33}$ Given these recurring images, I believe it is crucial to engage in an in-depth historical analysis of situations where migration was a driving force for emancipatory change.

\section{Migration and the Creation of New Ideas and Practices}

In fact, the 'contribution of migration to the creation of new ideas (not just their spread) has been underemphasised in previous analyses'. ${ }^{14}$ Patrick Manning sees especially cross-community migration as driving development. However, by characterising this form of migration as male,

\footnotetext{
${ }^{11}$ See the broadcast produced by DRS aktuell (Swiss Radio and Television), 23 December 1983.

12 'Im übrigen lebt die Ehefrau aus südlichen Regionen mehr als die Schweizerin im Familienkreis. Sie hat wenige Kontaktmöglichkeiten mit der Aussenwelt, obschon die Erwerbsquote bei den verheirateten Ausländerinnen verhältnismässig hoch liegt'. Eidgenössische Konsultativkommission für das Ausländerproblem, Menschliche Probleme der Arbeitskräfte und ibrer Familienangehörigen, Bern: EKA 1976, 20.

${ }^{13}$ Gayatri Spivak, Can the Subaltern Speak?, in Grossberg and Nelson, Marxism and the Interpretation of Culture, Urbana: Chicago University of Illinois Press 1988, 271-316, 296.

${ }^{14}$ Patrick Manning, Cross-Community Migration: A Distinctive Human Pattern, Social Evolution \& History 5, 2 (2006), 24-54, 46.
} 
he marginalises females as historical agents, as Donna Gabaccia has rightly pointed out. ${ }^{15}$ Moreover, " $[\mathrm{m}]$ oving from the countryside to the nearest town or city can be just as much an occasion of knowledge creation as the relocation from one continent to another', as Simone Lässig and Swen Steinberg have convincingly argued by, at the same time, highlighting how productive the intersection between the history of knowledge and the history of migration is. ${ }^{16}$ It is therefore not a coincidence that people with some kind of migration experience have often developed a different view of history. In the field of migration research, too, scientific innovation often originated from people with migration experience. ${ }^{17}$

Once our attention has been drawn to such historical processes, important aspects of the past appear in a new light. For instance, when certain privileges intersect with specific forms of discrimination, the resulting situations offer the potential for new social and political configurations, as we have seen in relation to various examples. Likewise, the knowledge and motivation needed to push for change can circulate through various forms of migration and new networks and alliances of resistance can thereby be forged. ${ }^{18}$ Moreover, those who happen to not comply with a norm because they are used to different standards of

${ }^{15}$ Donna R. Gabaccia, Gender and Migration, in Ness, The Encyclopedia of Global Human Migration, Malden: Wiley-Blackwell 2013, https://onlinelibrary.wiley.com/doi/ book/10.1002/9781444351071 (3 Febraury 2014).

${ }^{16}$ Simone Lässig and Swen Steinberg, Knowledge on the Move: New Approaches Towards a History of Migrant Knowledge, Geschichte und Gesellschaft 43, 3 (2017), 313$346,316$.

${ }^{17}$ Helma Lutz and Kathy Davis, Biographische Grenzüberschreitungen und feministische Imagionation: Avtar Brah, Seyla Benhabib und Rosi Braidotti, in Lutz, Gender mobil? Geschlecht und Migration in transnationalen Räumen, Münster: Verlag Westfälisches Dampfboot 2009, 251-270; Kijan Espahangizi, Migrationsforschung und epistemische Teilhabe. Vier historische Schlaglichter auf die Zürcher 'Fremdarbeitersoziologie' in den 1970er Jahren, in Morawek and Krenn, Urban Citizenship. Demokratisierung der Demokratie, Wien: VfmK 2017, 89-111; Kijan Espahangizi, The Granddaughter's Dissertation: Some Thoughts on Knowledge about Migration in 1960s Switzerland (2017), https://historyofknowledge.net/2017/08/10/the-granddaughters-dissertation/ (4 June 2018).

${ }^{18}$ I analyse this topic in relation to deportations during Italian Fascism in Francesca Falk, Deportations, the Spreading of Dissent and the Development of Democracy. The confino on Ponza and Ventotene during Italian Fascism and its Political Aftermath, Journal of Migration History, forthcoming. 
behaviour may even unintentionally call these very norms into question. In addition, since relationships of power are naturalised by their everyday presence, they can sometimes be more easily perceived by newcomers. Their gaze can defamiliarise the familiar ${ }^{19}$ and in this way produce an 'awareness of alternatives', as Peter Burke has pointed out. ${ }^{20}$

As interviews with aging couples who migrated from Italy to Switzerland have shown, the experience of leaving a familiar environment and finding one's way in a new one-which often does not classify 'migrants' as belonging - can provide specific resources. ${ }^{21}$ These can be helpful in later stages of life, which are also associated with the loss of familiar contexts and thereby producing constraints for reorientation. Experiences of migration thus prove to be a specific 'capital' for dealing with changes and uncertainties. This is all the more important because individuals with experiences of migration are often confronted with specific difficulties upon retirement, for example, with regard to their pension. However, if today the so-called guest workers can also be seen as pioneers of globalisation, ${ }^{22}$ then the burden often associated with this experience of migration must not be forgotten. Nor should globalisation be glorified. Nevertheless, it is important to emphasise such resources, as they usually fall out of the picture. ${ }^{23}$

\section{Changing the Perspective Under Which Our Past Is Told And Our Future Imagined}

The approach proposed here does not merely consist in adding new information to an established account, but, in fact, to change perspectives and thereby to challenge some fundamental assumptions.

${ }^{19}$ Lloyd S. Kramer, Threshold of a New World. Intellectuals and the Exile Experience in Paris, 1830-1848, Ithaca, London: Cornell University Press 1988, 2.

${ }^{20}$ Peter Burke, Exiles and Expatriates in the History of Knowledge, 1500-2000, Waltham, MA: Brandeis University Press 2017, 23.

${ }^{21}$ In what follows, see Eva Soom Ammann, Ein Leben hier gemacht. Altern in der Migration aus biographischer Perspektive. Italienische Ehepaare in der Schweiz, Bielefeld: Transcript 2011.

${ }^{22}$ Erol Yildiz, Einleitung, in Yildiz and Hill, Nach der Migration. Postmigrantische Perspektiven jenseits der Parallelgesellschaft, Bielefeld: Transcript 2015, 9-16, 11.

${ }^{23}$ With regard to the specific resources of the so-called second generation, see Rohit Jain, Kosmopolitische Pioniere: 'Inder_innen der zweiten Generation' aus der Schweiz zwischen Assimilation, Exotik und globaler Moderne, Bielefeld: Transcript 2018. 
For instance, assertions have been made which become much more complicated if the living conditions of 'migrants' are taken into account. See, for instance, the statement that in these boom years, the opportunity to live on a single income made the employment of women optional. If we look at 'migrant' families, the limitations of this statement immediately catch our eye.

Whereas over the past decades, 'dozens of publications have thus appeared that started out by saying that the field of gender and migration is in general underresearched', ${ }^{24}$ this observation no longer holds true today. Nevertheless, the literature is still lopsided, and many stimulating questions await a systematic investigation, as we have seen.

Of course, the examples I have analysed in this contribution are not intended to suggest that, for all possible phenomena related to changing gender relations, migration was the decisive factor. Sometimes, migration is only one factor among many (new ideas and role models can, for instance, circulate via the media). In addition, I am obviously aware that migration characterises our society in many different and sometimes ambiguous ways and that my investigation necessarily privileges the 'productive' aspects of it. My findings do not imply therefore that migration can never be an obstacle in the struggle for gender equality. In regard to highly skilled 'migrant' women in Switzerland, Yvonne Riaño has shown, for instance, that traditional ideas about gender roles, discourses about ethnic difference, and discriminatory migration policies intersect and hinder these women from accessing the upper segments of the Swiss labour market. For them, '[m]igration, therefore, does not always imply empowerment and emancipation, but also generates new forms of social inequality'. ${ }^{25}$ Mirjana Morokvasic also critises a simplistic perception of emigration as empowerment. ${ }^{26}$ Nor do I argue that we should allow only those migrations that benefit the receiving society. From my perspective,

\footnotetext{
${ }^{24}$ Marlou Schrover, Europe: Gender and Migration, in Ness, The Encyclopedia of Global Human Migration, Malden: Wyler 2013, https://onlinelibrary.wiley.com/doi/ book/10.1002/9781444351071 (3 Febraury 2014).

${ }^{25}$ Yvonne Riaño, Drawing New Boundaries of Participation: Experiences and Strategies of Economic Citizenship among Skilled Migrant Women in Switzerland, Environment and Planning 43, 7 (2011), 1530-1546, 1530.

${ }^{26}$ Mirjana Morokvasic, Migration, Gender, Empowerment, in Lutz, Gender mobil? Geschlecht und Migration in transnationalen Räumen, Münster: Westfälisches Dampfboot 2009, 28-51; Mirjana Morokvasic, Gender, Labour, and Migration, in Ness, The Encyclopedia of Global Human Migration, Malden: Wiley 2013.
} 
the legitimacy of migration does not depend on whether it is useful for any particular individual or group. ${ }^{27}$ Finally, my focus on the complex links between migration and gender equality should not be equated with the promotion of a single, linear success story. Ambiguity, counter-movements, setbacks, and moments of failure are, as we know, always part of history. ${ }^{28}$ And of course, the argument is not that all 'migrants' are politically progressive, which is obviously not the case. It is quite well-known that the experience of migration can sometimes also lead to an increased conservatism, also in regard to gender relations. Moreover, there are clear limitations to this study. For instance, in the examples analysed in this book, the existence of two genders is not questioned. This book has therefore a direction, but no end. Many other fields would be worthwhile to investigate.

What my findings do show, however, is that contemporary and historiographical discourses which predominantly frame migration as a problem to be tackled neglect the historical evidence for sociopolitical innovation that can, at times, result from international, transnational,

${ }^{27}$ The philosopher Andreas Cassee, for example, demands that every person should be free to decide in which country he or she wants to live. From such a perspective, restrictions on immigration are only permissible in exceptional situations. Andreas Cassee, Globale Bewegungsfreiheit. Ein philosophisches Plädoyer für offene Grenzen, Berlin: Suhrkamp 2016.

${ }^{28}$ I can give here three very different examples indicating such forms of ambiguity, counter-movements, and setbacks. For instance, it has been argued that the more legal hindrances women have broken through, the more heavily images of female beauty have come to weigh upon them. Naomi Wolf, The Beauty Myth, London: Chatto \& Windus 1990.

Another example for a very concrete setback is the fact that since 2003 , the proportion of women has been declining in the Swiss Council of States, https://www.parlament.ch/ de $/ \%$ C3\%BCber-das-parlament/fakten-und-zahlen/zahlen-ratsmitglieder (27 April 2018).

Furthermore, feminist positions were integrated with ambivalent consequences into a neoliberal agenda. For instance, emancipatory demands were incorporated under very specific conditions, in a way that the flexibilisation of working hours, an important feminist demand of the new women's movement, led to the fact that employers now have more easily access to workers at home. Patricia Purtschert and Nina Apin, 'Ich ärgere mich den ganzen Tag! Dauernd!' (2017), http://www.taz.de/Archiv-Suche/!5397174\&s=nina+api n\&SuchRahmen=Print (1 June 2017). 
internal, and even indirect experiences of migration. ${ }^{29}$ It is only from a historical perspective that we can recognise how profoundly the social and political developments are shaped by migration. ${ }^{30}$

To illuminate the link between migration and what I call gender innovation does not mean to glorify migration or to propagate a naïve notion of diversity. ${ }^{31}$ Migration is per se neither good nor bad, but the conditions under which it takes place are good or bad, and these conditions are made, not given. The political, economic, and social conditions under which migration takes place depend on how past and present migration is perceived. This is precisely why, today, we have to make visible these often hidden histories. Looking at history through the lens of migration not only adds some new insights to an established body of work, but changes the perspective under which our past and thus also our present is told-and our future imagined.

\footnotetext{
${ }^{29}$ Walter Leimgruber has repeatedly stressed the importance of such a perspective. Walter Leimgruber, Die Tücken der Entgrenzung. Migration und Migrationsforschung vor neuen Herausforderungen, in Picard, Chakkalakal, and Andris, Grenzen aus kulturwissenschaftlichen Perspektiven, Berlin: Panama Verlag 2016, 269-296; Walter Leimgruber, Demokratische Rechte auf Nicht-Staatsbürger ausweiten, in Abbt and Rochel, Migrationsland Schweiz. 15 Vorschläge für die Zukunft, Baden: Hier und Jetzt 2016, 21-37.

${ }^{30}$ In this context, a highly interesting institute is the newly founded INES: https://institutneueschweiz.ch (12 September 2017).

${ }^{31}$ For a critical perspective on migration perceived as either a problem or as potential see Kijan Espahangizi, Im Wartesaal der Integration, in: terra cognita. Potenzial. Potentiel. Potenziale 27 (2015), 104-108; Rohit Jain, 'Sprichst Du Hindi?'—die zweite Generation zwischen Potenzial und Problem, terra cognita. Potenzial. Potentiel. Potenziale 27 (2015), 94-97; Rohit Jain and Shalini Randeria, Wider den Migrationskomplex-Perspektiven auf eine andere Schweiz, in Sozialalmanach. Herein: Alle(s) für die Zuwanderung (2015), 199-210.
} 
Open Access This chapter is licensed under the terms of the Creative Commons Attribution-NonCommercial-NoDerivatives 4.0 International License (http://creativecommons.org/licenses/by-nc-nd/4.0/), which permits any noncommercial use, sharing, distribution and reproduction in any medium or format, as long as you give appropriate credit to the original author(s) and the source, provide a link to the Creative Commons license and indicate if you modified the licensed material. You do not have permission under this license to share adapted material derived from this chapter or parts of it.

The images or other third party material in this chapter are included in the chapter's Creative Commons license, unless indicated otherwise in a credit line to the material. If material is not included in the chapter's Creative Commons license and your intended use is not permitted by statutory regulation or exceeds the permitted use, you will need to obtain permission directly from the copyright holder.

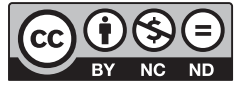

